\title{
Korte signaleringen
}

\author{
HARRY A. POEZE
}

\begin{abstract}
Pauline Lunsingh Scheurleer, Goud uit Java / Gold from Java. Zwolle: WBooks, Den Haag: Gemeentemuseum, 2012, 144 pp. ISBN 978.90.400.0360.8. Prijs €24,95.

Titus M. Eliëns, Zilver uit Batavia / Silver from Batavia. Zwolle: WBooks, Den Haag: Gemeentemuseum, 2012, 181 pp. ISBN 978.90.400.0361.5. Prijs € 27,95.
\end{abstract}

Het Haagse Gemeentemuseum organiseerde in 2012 twee tentoonstellingen met kunstnijverheid, grotendeels uit eigen bezit: 'Goud uit Java' en 'Zilver uit Batavia'. Beide kregen een eigen tweetalige monografie, waarin na een ruimschootse inleiding alle geëxposeerde voorwerpen zijn afgebeeld en van toelichting voorzien. Het goud dateert uit de Hindoe-Boeddhistische cultuur die van 200 tot 1500 op Java heerste. Haar nalatenschap vormen de stenen tempels, de stenen en bronzen beelden en een relatief groot aantal gouden voorwerpen, vooral sieraden. Er is nog weinig onderzoek naar dit goud verricht, en datering, gebruik en betekenis zijn vaak problematisch. Pauline Lunsingh Scheurleer geeft eerst een kenschets van de cultuurperiode en de overgeleverde oudheden en doet daarna een bewonderenswaardige poging de voorwerpen in hun context te plaatsen - en zij komt daarbij heel ver. Titus M. Eliëns heeft het met het zilver uit Batavia relatief gemakkelijker. Dit zilverwerk werd in de VOC-tijd vervaardigd in de late zeventiende en de achttiende eeuw. Zilversmeden uit Nederland en elders uit Europa en Indiase en Indische assistenten produceerden bestek en serviezen, tabak- en sirihdozen en gedenkborden. Keuren en keurmeesters waarborgden zuiverheid en kwaliteit. In de Haagse museumcollectie zijn, volgens de meestertekens, voorwerpen van 26 smeden aanwezig; van elf van hen is de volledige naam opgespoord. In beide boeken - verantwoorde wetenschappelijke werkstukken - is het fotowerk van de allerhoogste kwaliteit. Daarmee doet uitgever WBooks, de opvolger van Waanders, zijn afkomst eer aan. 
P.J. Rietbergen, De Verenigde Oost-Indische Compagnie, 16021795: 's Werelds eerste multinational tussen commercie en cultuur. Amersfoort/Brugge: Bekking en Blitz, 2012, 144 pp. [Miniaturen Reeks 52.] ISBN 978.906109.4265. Prijs € 9,90.

In een aantrekkelijke uitvoering, en voor een dito prijs, schreef de Nijmeegse hoogleraar cultuurgeschiedenis P.J. Rietbergen een beknopte geschiedenis van de Verenigde Oost-Indische Compagnie. De ondertitel verraadt reeds Rietbergens visie: de VOC was de eerste multinational ooit, een vennootschap op aandelen die tweehonderd jaar lang actief was en voor vele superlatieven stond zoals de uitzending van een miljoen personeelsleden naar de Oost op 1500 schepen die 4800 reizen maakten. Met haar activiteiten stond de VOC aan de wieg van de globalisering. De VOC was allereerst een handelsbedrijf dat slechts met grote aarzeling en beperkt de weg opging naar kolonisatie en, in het verlengde daarvan, kerstening. Geweld stond in het teken van de handelsbelangen. Daarbij speelde de VOC zijn rol als een van de machten daar, die in China, Japan en Indiase rijken zijn meerdere moest erkennen. In dit kader wijst Rietbergen kenschetsen van de VOC met kolonialisme en imperialisme af. Hij heeft veel aandacht voor cultuur en wetenschap zoals die in Nederland en in de Oost elkaar wederzijds beïnvloedden. De ondergang van de VOC wijt hij niet aan corruptie, maar aan de economische neergang, de tekortschietende boekhouding en de oorlogen in Europa. Zo is dit een nuttig boekje, dat in handzaam formaat de VOC-historie samenvat en waarin daarnaast Rietbergen ook zijn eigen geluid laat horen.

Clemens Verhoeven, Het vergeten korps: De geschiedenis van de Koloniale Reserve. Nijmegen: Vantilt/fragma, 2012, 255 pp. ISBN 978.90.814500.3.4. Prijs $€ 29,50$.

De werving van troepen voor Indië was al in het VOC-tijdperk een bron van zorg en bleef dat tot het einde van het Nederlands koloniale bestuur. Het Koninklijk Nederlands-Indisch Leger, in 1830 gevormd, was voor de toestroom van zijn manschappen aangewezen op het Koloniaal Werfdepot in Harderwijk, waarvan de bijnaam 'het riool van Europa' voldoende zegt over het gehalte van de rekruten die zich uit geheel Europa meldden voor een risicovolle inzet in Indië. Aan het einde van de negentiende eeuw werden de uitwassen niet meer als acceptabel beschouwd, en werd het Depot gereorganiseerd en uiteindelijk in 1909 gesloten. De Koloniale Reserve, in 1890 bij wet ingesteld, nam de plaats van het Depot in. In Nijmegen werd een grote, moderne kazerne gebouwd, met daarnaast een hospitaal. De Reserve stond alleen 
open voor Nederlanders en de strenge selectie werd slechts overleefd door tien procent van de aanmelders. De beeldvorming was goed, de werkvoorwaarden relatief gunstig en het verblijf in een exotische kolonie aanlokkelijk. In Nijmegen werd werving en selectie van de manschappen verzorgd. In Kampen kon in vier jaar in het zogenoemde 'Instructiebataljon' een officiersrang in het KNIL worden verdiend. De Cadettenschool in Alkmaar fungeerde als tweejarige voorbereiding voor de Koninklijke Militaire Academie in Breda, waar ook KNIL-officieren werden opgeleid. Naast de Nijmeegse kazerne waren er hospitalen voor gewonde en zieke soldaten en was er opvang voor verlofgangers, veteranen en gehandicapten, waarbij ook het Arnhemse landgoed Bronbeek - dat sinds 1863 als museum was ingericht - een rol speelde. Over het Werfdepot publiceerde Martin Bossenbroek twee boeken. Over de Koloniale Reserve is er nu voor het eerst een overzichtswerk: Het vergeten korps. Op groot formaat en met 140 bladzijden illustraties beschrijft Clemens Verhoeven, gebaseerd op allerlei verspreide bronnen, de werving van KNILmanschappen en alles wat daarmee samenhing. Het resultaat is een verhelderend lees- en kijkboek, in fraaie vormgeving.

N.S. Efthymiou, Grondrechten in Nederlands-Indië. Nijmegen: Wolf Legal Publishers, 2011, viii+137 pp. ISBN 978.90.5850.761.7. Prijs $€ 24,95$.

Constitutioneel recht gold in Nederlands-Indië al sinds 1602, maar van een democratische rechtsstaat was in geen enkel opzicht sprake. Met het Regeringsreglement van 1854 veranderde dat, en kwam er ook ruimte voor grondrechten, de waarborging waarvan een van de kenmerken van zo'n rechtsstaat is.

De Indische Staatsregeling legde in 1926 de regels opnieuw vast, tot de Japanse bezetting in 1942. N.S. Efthymiou, universitair docent in Rotterdam, promoveerde in 2005 op een omvangrijke dissertatie 'De organisatie van regelgeving voor Nederlands Oost-Indië', waarvan Grondrechten in NederlandsIndië een handzame ontlening vormt. Grondrechten waren in Nederland geen onderwerp dat grote aandacht trok en voor de kolonie gold dat nog minder. Voor Indië werd de toepassing nog gecompliceerd door het verschil tussen direct en indirect bestuurd gebied, en het wettelijk onderscheid tussen Europeanen, inlanders en Vreemde Oosterlingen, een rechtsdualisme dat ook op de grondrechten zijn weerslag had.

Zeven grondrechten worden door de auteur behandeld: persoonlijke vrijheid, bescherming van vermogensrechten, vrijheid van meningsuiting, vereniging en vergadering, vrijheid van godsdienst, briefgeheim en petitie. 
De wetsgeschiedenis en tekstinterpretatie worden behandeld en ook de nadere regelgeving over deze rechten.

De principiële formulering van deze grondrechten is vaak ruimhartig, met uitzondering van de regels over inhechtenisneming en de 'exorbitante' rechten van de gouverneur-generaal tot verbanning en internering. In de uitwerking echter wordt, om op te treden tegen politiek ongewenste Indonesische organisaties steeds vaker regelgeving vastgesteld die de politiek relevante grondrechten ernstig inperken, vaak ook door bestuurlijke bevoegdheden, zonder rechterlijke inbreng. Het onderscheid in rechtstoedeling tussen bevolkingsgroepen werd hiermee versterkt. Efthyniou concludeert dat de kwaliteitsbescherming van de grondrechten vraagtekens oproept, maar hij gaat niet zo ver de toepassing van de grondrechten ondermaats te noemen.

Efthymiou heeft nog meer plannen over het Indische constitutionele recht te publiceren, en dat zal ongetwijfeld even verhelderend als dit boekje zijn.

F.J.A.M. van der Helm, M.B. Rost van Tonningen (1852-1927): Het familieleven van de Lombokgeneraal. Hoogwoud: Kirjaboek, 2012, 239 pp. ISBN 978.94.6008.140.8. Prijs $€ 17$.

Marinus Bernardus Rost van Tonningen werd in 1852 in Paramaribo geboren, waar zijn vader Nicolaas Albertus (1819-1878) was gelegerd. Diens loopbaan verliep voorspoedig en eindigde als gezaghebber van Sint-Eustatius. Marinus' jeugd speelde zich af op dit verre eiland. Hij werd vervolgens toegelaten als kadet voor het KNIL aan de Koninklijke Militaire Akademie in Breda. Er volgde een Indische carrière die voorspoedig verliep: van tweede luitenant in 1872 tot luitenant-generaal en opperbevelhebber van het KNIL in 1907. In 1909 ging hij met pensioen. In die jaren was hij actief in de Atjeh-oorlog en bij expedities op Lombok en Bali. Het leverde hem twee keer een Militaire Willemsorde op. Het grootste deel van zijn militaire jaren was hij echter geplaatst in Batavia. Tijdens zijn Nederlands verlof werd hij benoemd tot adjudant van koningin Wilhelmina en had hij een rol in haar inhuldiging in 1898. Zijn ogenschijnlijk niet heel bijzondere loopbaan eindigde niettemin in de hoogste legerfunctie - het gevolg van goede relaties? Wellicht droeg hier ook toe bij zijn huwelijk met freule Van den Bosch - een duidelijke opwaartse mobiliteit.

Op zulke vragen gaat Van der Helms biografie niet in. Hij beperkt zich tot het familieleven van de generaal, zoals hij dat samenvat uit het omvangrijke archief van de familie Rost van Tonningen. Hij waarschuwt de lezer ook meteen dat hij die keuze maakt, maar dat doet er niets aan af dat het resultaat onvolledig en onbevredigend is. 
Ook op de presentatie van het gebruikte materiaal is wel iets aan te merken. Van der Helm trekt nogal vergaande conclusies, psychologiseert er lustig op los en zijn stijl komt regelmatig in de richting van oubolligheid. Niettemin brengt hij onbekende gegevens bijeen, ook over Marinus' jongste zoon Meinoud (1894-1945), die als voorman van het Nederlandse fascisme en collaborateur met de Duitse bezetter een notoire reputatie verkreeg.

Hans Goedkoop, De laatste man: Een herinnering. Amsterdam/ Antwerpen: Augustus, 93 pp. ISBN 978.90.457.0574.3. Prijs $€$ 14,95 .

De historicus Hans Goedkoop (1963) is de bekroonde biograaf van Herman Heijermans en presentator van het tv-programma 'Andere tijden'. Hij verdiepte zich pas laat, na diens dood, in de levensloop van zijn grootvader D.R.A. van Langen (1898-1983), die zijn glansrijke loopbaan in het KNIL afsloot als generaal en chef-staf in 1950, toen het KNIL werd opgeheven en Indonesië onafhankelijk werd. Hij speelde een belangrijke rol bij het verzekeren van een ordelijke liquidatie van het KNIL in juli 1950, toen de Indonesische KNILmanschappen dreigden te muiten of zelfs ten strijde wilden trekken tegen de Republik Indonesia. Hij kreeg hiervoor een hoge onderscheiding maar na terugkeer in Nederland was er geen legerfunctie meer voor hem. Hij werd op een zijspoor gezet als brandweeradviseur. Goedkoop doet verslag van zijn speurtocht, vooral in archieven, naar de reden hiervoor en het geheim hierachter. Van Langen was betrokken bij de smokkel van Westerling naar Singapore, na diens actie tegen de Indonesische regering in maart 1950, maar na aanvankelijke boosheid hierover werd erkend dat hij zo veel diplomatiek rumoer had voorkomen. Tenslotte vindt Goedkoop de nota's van april 1950 en later waarin Van Langen suggereert het KNIL te laten optreden tegen de regering-Soekarno, die naar zijn oordeel afgleed in communistische richting. Voor de Nederlandse regering was dit spelen met vuur. Van Langen kreeg een terechtwijzing en zijn nota's werden veilig opgeborgen. Van Langen had gekozen voor zijn Indonesische KNIL-manschappen die in een onmogelijke positie waren beland. Het was een rechtlijnige keuze, trouw aan de koloniale erfenis. Maar zijn geluid mocht in Nederland niet worden gehoord. Het slechte geweten van de Nederlandse beleidsmakers over de afwikkeling van de Indische erfenis leidde tot Van Langens buitensluiting - hij werd verwijderd uit de hoogste defensiekringen. Goedkoop heeft een mooi, ruim geilllustreerd boekje geschreven, met veel inzet en emotie, dat geen 'echte' biografie is, maar vooral een persoonlijke zoektocht naar de drijfveren van zijn grootvader. 
J.A.A. van Doorn en W.J. Hendrix, Ontsporing van geweld: Het Nederlands-Indonesisch conflict. Meteennawoord vanDirk Vlasblom. Zutphen: Walburg Pers, 2012, 367 pp. ISBN 90.5730.886.X. Prijs $€$ 29,50 .

In januari 1969 veroorzaakte Indiëveteraan Joop Hueting ongekende opschudding toen hij in een televisieprogramma vertelde dat Nederlandse troepen in Indonesië zich tijdens het dekolonisatieconflict (1945-1949) op aanzienlijke schaal hadden schuldig gemaakt aan oorlogsmisdaden. Honderden persartikelen volgden, waarin vaak met veel emotie veteranen van hun instemming en - vaker - hun afkeuring lieten blijken. Het vervolg was een overheidsopdracht inventariserend archiefonderzoek te verrichten naar het Nederlandse militaire optreden. Het resultaat was de 'Excessennota'. Dit voorlopige verslag kreeg geen vervolg. Het voorstel tot een parlementaire enquête werd verworpen en de stilte daalde neer over dit ongemakkelijke onderwerp. De discussie flakkerde met enige regelmaat op, maar leidde nooit tot een uitgebreid onderzoek naar aard, omvang en verklaring van het geweld en de definitie ervan als exces of oorlogsmisdaad. Ook nu is er weer discussie en ligt er het voorstel van drie wetenschappelijke instituten (KITLV, NIOD en Nederlands Instituut voor Militaire Historie) om tot een alomvattend onderzoek hierover te komen. Dit was een belangrijke aanleiding voor de vierde druk van Ontsporing van geweld dat voor het eerst in 1970 verscheen. Van Doorn (1925-2008) en Hendrix (1926) waren beiden soldaat op Midden-Java, en verzamelden materiaal voor hun boek tijdens hun inzet daar. Een uitgave van hun manuscript bleek pas mogelijk na Huetings onthullingen. Het boek combineert een sociologische analyse met gegevens uit het veld. Een overzicht van voorgeschiedenis en verloop van het conflict wordt vervolgd met een bespreking van troepeninzet en het gebruikte geweld en de excessen daarbij, met tot slot het eigen bataljon als casestudy. Het boek is - nog steeds - een opmerkelijke, grotendeels valide en heldere uiteenzetting over het geweld in Indonesië, dat ongetwijfeld een basis zal vormen voor de voorgestelde nieuwe, noodzakelijke studies over dit onderwerp. 